\title{
Parsing Genetically Influenced Risk Pathways: Genetic Loci Impact Problematic Alcohol Use Via Externalizing and Specific Risk
}

Peter B. Barr, Ph.D. ${ }^{1}$, Travis T. Mallard, Ph.D. ${ }^{2}$, Sandra Sanchez-Roige, Ph.D. ${ }^{3,4}$, Holly E. Poore, Ph.D. ' , Richard Karlsson Linnér, Ph.D. ${ }^{5}$, COGA Collaborators, Irwin D. Waldman, Ph.D. ${ }^{6,7}$, Abraham A. Palmer, Ph.D. ${ }^{3,8}$, K. Paige Harden, Ph.D. ${ }^{2,9}$, and Danielle M. Dick, Ph.D. ${ }^{1,10}$

\section{Affiliations:}

${ }^{1}$ Department of Psychology, Virginia Commonwealth University, Richmond, VA, USA.

${ }^{2}$ Department of Psychology, University of Texas at Austin, Austin, TX, USA.

${ }^{3}$ Department of Psychiatry, University of California San Diego, La Jolla, CA, USA.

${ }^{4}$ Division of Genetic Medicine, Vanderbilt University Medical Center, Nashville, TN, USA

${ }^{5}$ Department of Economics, Vrije Universiteit Amsterdam, Amsterdam, Netherlands.

${ }^{6}$ Department of Psychology, Emory University, Atlanta, GA, USA.

${ }^{7}$ Center for Computational and Quantitative Genetics, Emory University, Atlanta, GA, USA.

${ }^{8}$ Institute for Genomic Medicine, University of California San Diego, La Jolla, CA, USA.

${ }^{9}$ Population Research Center, University of Texas at Austin, Austin, TX, USA.

${ }^{10}$ Department of Human and Molecular Genetics, Virginia Commonwealth University, Richmond, VA, USA. 
medRxiv preprint doi: https://doi.org/10.1101/2021.07.20.21260861; this version posted July 23, 2021. The copyright holder for this preprint (which was not certified by peer review) is the author/funder, who has granted medRxiv a license to display the preprint in perpetuity. It is made available under a CC-BY-NC 4.0 International license .

\begin{abstract}
Importance: Characterizing whether genetic variants for psychiatric outcomes operate via specific versus general pathways provides more informative measures of genetic risk, and, potentially, allows us to design more targeted prevention and interventions.
\end{abstract}

Objective: Employ multivariate methods to tease apart variants associated with problematic alcohol use through either general or specific pathways and compare results to standard univariate genetic analysis of problematic alcohol use.

Design: We compared results from a univariate genome wide association study (GWAS) of problematic alcohol use to those from a previous multivariate GWAS of externalizing phenotypes. We identified genetic variants associated with problematic alcohol use through a broad liability to externalizing, and those that remain after removing shared variance with externalizing. We compared these results across SNP overlap, bioannotations, genetic correlations, and polygenic scores.

Setting: We included GWAS summary statistics from existing GWAS, and two US based hold out samples: The National Longitudinal Study of Adolescent to Adult Health (Add Health) and the Collaborative Study on the Genetics of Alcoholism (COGA).

Participants: Publicly available GWAS of externalizing behaviors and participants in Add Health $(\mathrm{N}=5,107)$ and COGA $(\mathrm{N}=7,483)$, limited to individuals of European ancestries.

\title{
Exposure(s): N/A
}

Main Outcome(s) and Measure(s): Outcomes included problematic alcohol use (ALCP-O), shared risk for externalizing (EXT), and problematic alcohol use-specific risk (ALCP-S) for the 
medRxiv preprint doi: https://doi.org/10.1101/2021.07.20.21260861; this version posted July 23, 2021. The copyright holder for this preprint

(which was not certified by peer review) is the author/funder, who has granted medRxiv a license to display the preprint in perpetuity.

It is made available under a CC-BY-NC 4.0 International license .

GWASs; a preregistered list of 99 available phenotypes for genetic correlations; and substance use, substance use disorder criteria, and alcohol misuse in the polygenic score analyses.

Results: The analysis differentiated SNPs operating through common versus specific risk pathways. While ALCP-O was associated with multiple phenotypes, ALCP-S was predominantly associated with alcohol use and other forms of psychopathology. Polygenic scores for ALCP-O were associated with a variety of other forms of substance use and substance use disorders, polygenic scores for ALCP-S were only associated with alcohol phenotypes. Polygenic scores for both ALCP-S and EXT show differential patterns of associations with alcohol misuse across development.

Conclusions and Relevance: Focusing on the differential impacts of shared and specific risk can better characterize pathways of risk for alcohol use disorders. Multivariate methods can be a useful tool for studying many psychiatric conditions. Parsing risk pathways will become increasingly relevant as genetic information is incorporated into clinical practice for psychiatric outcomes. 
medRxiv preprint doi: https://doi.org/10.1101/2021.07.20.21260861; this version posted July 23, 2021. The copyright holder for this preprint (which was not certified by peer review) is the author/funder, who has granted medRxiv a license to display the preprint in perpetuity. It is made available under a CC-BY-NC 4.0 International license .

\section{Introduction}

Genome-wide association studies (GWAS) are rapidly advancing our ability to detect genetic loci associated with psychiatric and substance use disorders ${ }^{1-5}$. However, these disorders rarely occur in isolation, and GWAS of any given outcome will detect genetic loci related to that outcome via correlated traits. This non-specificity is evident in the ubiquitous genetic correlations detected across psychiatric traits ${ }^{1-5}$. Alcohol use disorders (AUDs) are no exception: AUD are moderately heritable $(\sim 50 \%)^{6}$, with most of the heritability of AUD shared with other externalizing phenotypes ${ }^{7-9}$, and a smaller proportion of genetic effects being specific to alcohol use outcomes ${ }^{7}$. New multivariate methods allow us to tease apart specific versus shared pathways by which genetic loci are associated with a given disorder ${ }^{10,11}$. Of particular relevance for the study of alcohol, a recent multivariate GWAS of externalizing phenotypes identified 579 loci associated with a shared genetic vulnerability to externalizing ${ }^{12}$. Here we apply these methods to differentiate genetic pathways for problematic alcohol use and demonstrate how moving beyond GWAS that focus on a single outcome may help us better understand how risk for various disorders unfolds.

Specifically, we expand upon an initial multivariate GWAS of externalizing to differentiate the genetic variants that impact problematic alcohol use through this broad externalizing liability (EXT), from variants that are specific to problematic alcohol use (ALCP-S). We compare our multivariate results to those from a previously published univariate GWAS of problematic alcohol use (the "original" GWAS results, or ALCP-O). Across these three GWAS results, we compare: 1) the genetic correlations with other relevant phenotypes; 2) the biological annotations of each genetic signal, and 3) the associations of polygenic scores (PGS) for each component with a variety of substance use phenotypes. Our analyses aim to better characterize the genetic pathways that impact problematic alcohol use and illustrate the use of multivariate genomic analyses to differentiate patterns of risk. 
medRxiv preprint doi: https://doi.org/10.1101/2021.07.20.21260861; this version posted July 23, 2021. The copyright holder for this preprint (which was not certified by peer review) is the author/funder, who has granted medRxiv a license to display the preprint in perpetuity.

\section{Methods}

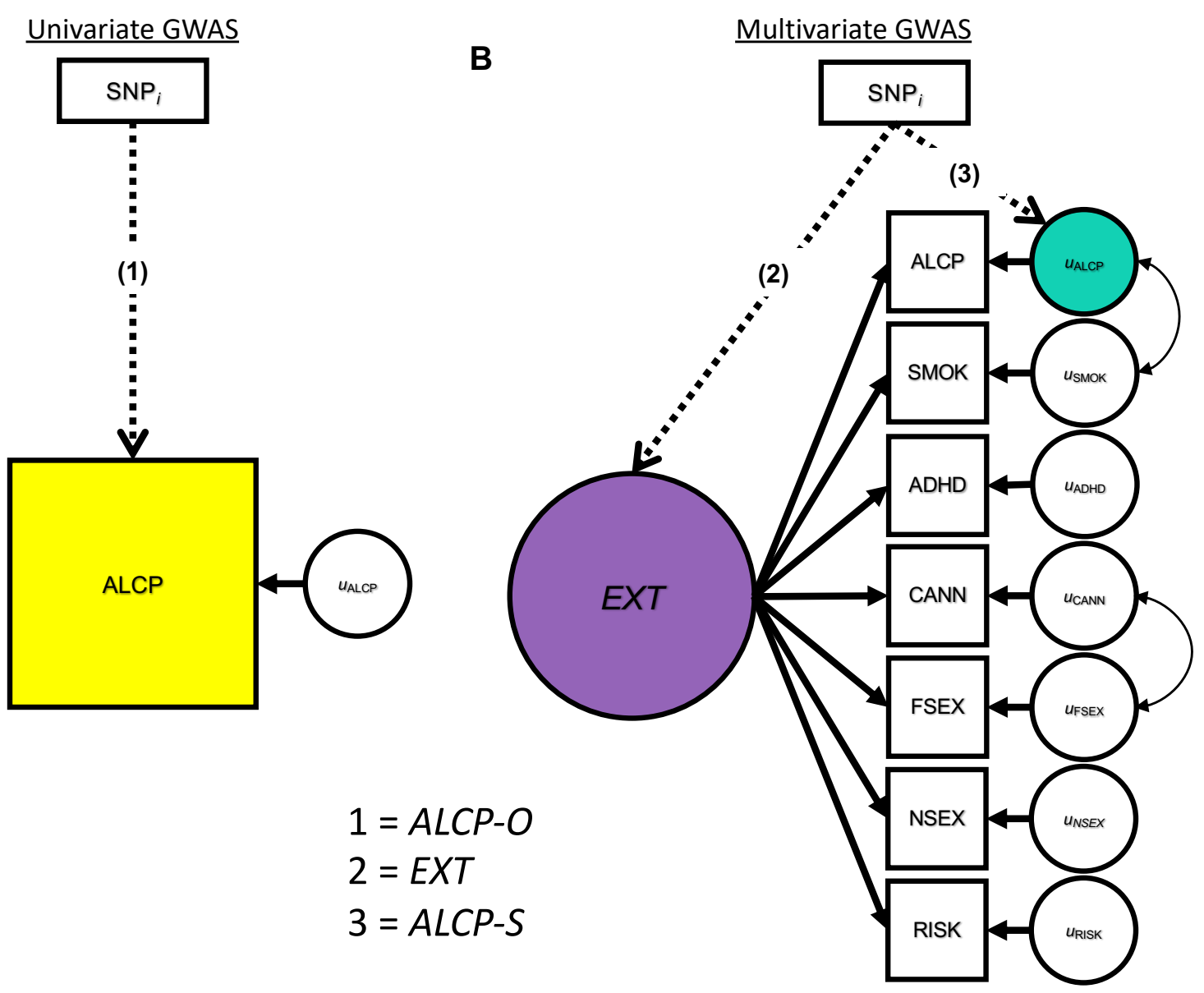

Figure 1: Univariate (A) and Multivariate (B) GWAS Models for Problematic Alcohol Use and Externalizing.

The SNP associations with the yellow box labeled ALCP are referred to herein as "ALCP-O" (original problematic alcohol use), the SNP associations with the purple circle are referred to herein as "EXT" (shared risk towards externalizing), and the SNP associations with the teal circle are referred to herein as "ALCP-S" (problematic alcohol use-specific). 
medRxiv preprint doi: https://doi.org/10.1101/2021.07.20.21260861; this version posted July 23, 2021. The copyright holder for this preprint

(which was not certified by peer review) is the author/funder, who has granted medRxiv a license to display the preprint in perpetuity.

It is made available under a CC-BY-NC 4.0 International license .

\section{GWAS of Problematic Alcohol Use Specific Variance}

In previous work ${ }^{12}$, we ran a common-factor, multivariate GWAS of externalizing using Genomic Structural Equation Modeling (Genomic SEM). The final model included summary statistics from seven phenotypes: (1) attention-deficit/hyperactivity disorder (ADHD), (2) problematic alcohol use (ALCP), (3) lifetime cannabis use (CANN), (4) age at first sexual intercourse (FSEX), (5) number of sexual partners (NSEX), (6) general risk tolerance (RISK), and (7) lifetime smoking initiation (SMOK). All analyses were limited to samples of European ancestry. We extended this model to simultaneously estimate the association between each single nucleotide polymorphism (SNP) and the residual variance in problematic alcohol use (ALCP-S), as, ALCP-S accounts for a large portion ( $75 \%)$ of the genetic variance (in addition to measurement error) in ALCP-O ${ }^{12}$.

Figure 1A displays the univariate GWAS, focusing on a single phenotype (ALCP-O). Figure 1B displays the multivariate GWAS, with the seven indicators used to estimate the model. From these two models, we derive three sets of GWAS summary statistics: the univariate GWAS results for ALCP-O (path 1), the common factor GWAS results for EXT (path $2)^{12}$, and the problematic alcohol use specific GWAS (path 3; ALCP-S). These three sets of results allow us to dissect genetic variance in problematic alcohol use by comparing the results of ALCP-O to both EXT and ALCP-S.

\section{Genetic correlations}

We estimated genetic correlations between EXT, ALCP-S, ALCP-O and 99 preregistered phenotypes not included in the original model. A full list of the genetic correlations is available in Supplementary Table 2. Genetic correlations allowed us to examine how patterns of associations differed across EXT, ALCP-O, and ALCP-S. We present the change in genetic correlations from ALCP-O to ALCP-S for phenotypes that were significantly associated with ALCP-O (after correcting for an $\mathrm{FDR}^{13}$ of $5 \%$ ). 
medRxiv preprint doi: https://doi.org/10.1101/2021.07.20.21260861; this version posted July 23, 2021. The copyright holder for this preprint (which was not certified by peer review) is the author/funder, who has granted medRxiv a license to display the preprint in perpetuity. It is made available under a CC-BY-NC 4.0 International license .

\section{Bioannotation}

To compare biological annotations from each of the GWAS sets (ALCP-O, ALCP-S, EXT), we performed a series of bioinformatic analyses, using a previously established pipeline $^{12}$. First, we used FUMA ${ }^{14}$ v1.2.8 to identify independent SNPs (LD threshold of $r^{2}<.1$ ) and conduced competitive gene-set, tissue and pathway analysis using MAGMA v1.08 ${ }^{15} .2$ ) Next, we used an extension of MAGMA, Hi-C coupled MAGMA (H-MAGMA) ${ }^{16}$, to assign noncoding (intergenic and intronic) SNPs to genes based on their chromatin interactions. Lastly, we used S-PrediXcan v0.6. $2^{17}$ to predict transcript abundance in 13 brain tissues, and to test whether the predicted transcripts showed divergent correlation patterns with each of the genetic factors.

Polygenic scores

We created polygenic scores (PGS) from each set of GWAS summary statistics in European-ancestry subjects from two independent cohorts: (1) the National Longitudinal Study of Adolescent to Adult Health ${ }^{18}$ (Add Health; $N=5,107$ ) and (2) the Collaborative Study on the Genetics of Alcoholism ${ }^{19,20}$ (COGA; $\left.N=7,594\right)$. Within each sample we created PGS for: 1 ) ALCP-O; 2) EXT; and 3) ALCP-S using PRS-CS, a Bayesian approach that uses a continuous shrinkage parameter to adjust GWAS summary statistics for linkage disequilibrium (LD) ${ }^{21}$.

Within each of the holdout samples, we compared the effect size (incremental $R^{2}$ above a covariate-only model with age, sex, and the first ten ancestral principal components) of the association of each PGS with criterion counts of AUD. Next, we compared the association of ALCP-O and ALCP-S PGS with four other substance categories, including nicotine, cannabis, opioids (COGA only), and other illicit substances (e.g., cocaine, sedatives, stimulants, methamphetamine). Substance phenotypes included "ever use" and SUD criterion counts. We corrected all analyses for multiple testing using an $\mathrm{FDR}^{13}$ of $5 \%$. 
Finally, we compared the association between the EXT and ALCP-S PGSs with an alcohol use index $(\mathrm{AUI})^{22}$ across time in Add Health. This composite index included five alcohol phenotypes ranging from normative to problematic use, scaled to a value of 0 to $10^{22}$. We fit a growth model using a linear mixed model with the Add Health data structured on age. Our longitudinal analyses were limited to Add Health due to the low sample attrition across time. Detailed descriptions of the holdout samples, phenotypes, and analyses are presented in Supplementary Note 4. 
medRxiv preprint doi: https://doi.org/10.1101/2021.07.20.21260861; this version posted July 23, 2021. The copyright holder for this preprint (which was not certified by peer review) is the author/funder, who has granted medRxiv a license to display the preprint in perpetuity.

\section{It is made available under a CC-BY-NC 4.0 International license .}

\section{Results}

\section{Genetic Correlations, Lead SNPs, and Bioannotations}

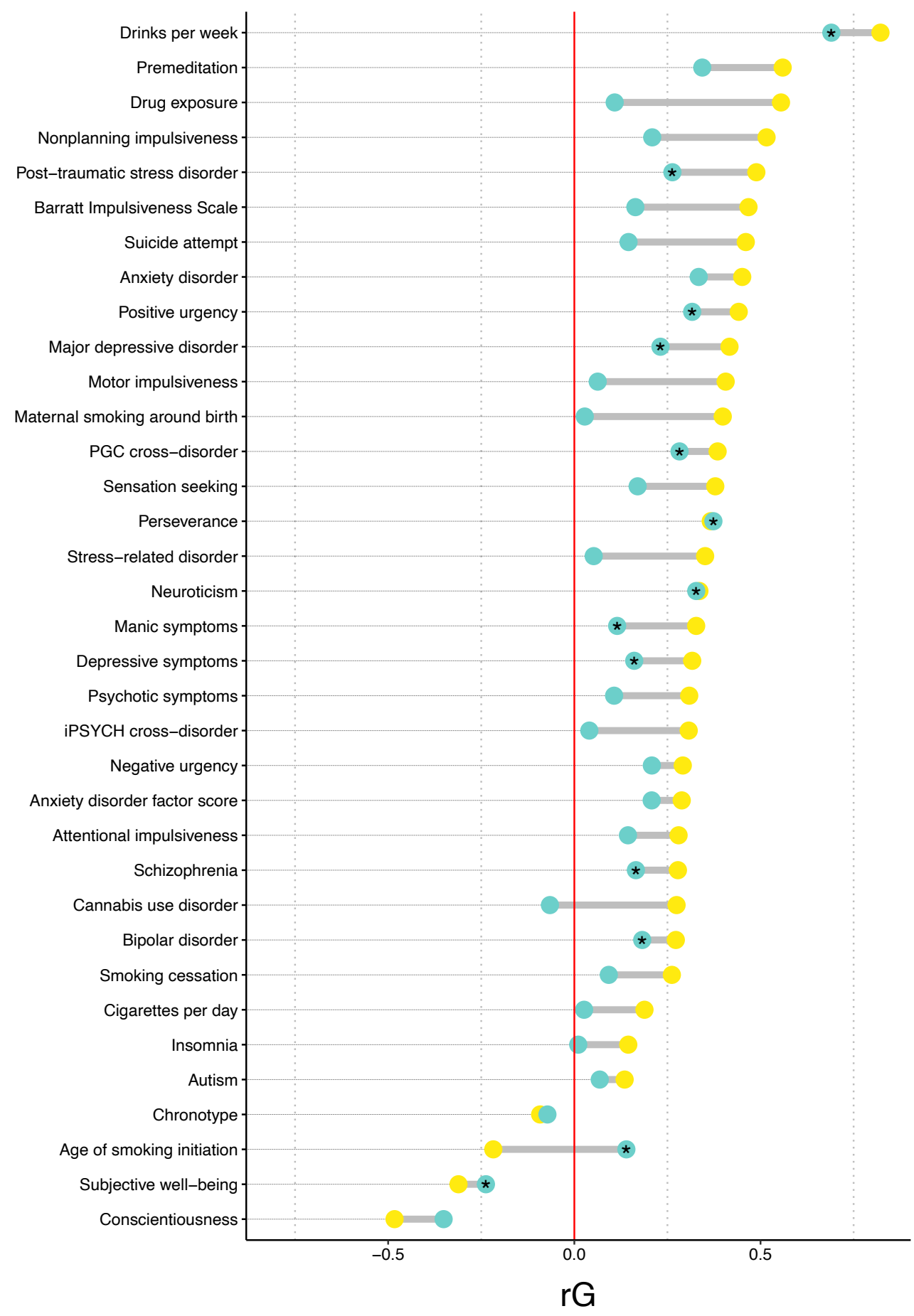

Figure 2: Differences in Genetic Correlations for ALCP-O and ALCP-S

Changes in genetic correlations $\left(r_{g}\right)$ from problematic alcohol use (ALCP-O, yellow dots) to problematic alcohol usespecific (ALCP-S, teal dots) across a subset of phenotypes that are significantly correlated with ALCP-O (after correcting for an FDR of $5 \%$, Supplementary Table 2 reports all pre-registered genetic correlations). Asterisks ( $\left.{ }^{*}\right)$ represent genetic correlations for ALCP-S that are still significant (after correcting for an FDR of $5 \%$ ). 
medRxiv preprint doi: https://doi.org/10.1101/2021.07.20.21260861; this version posted July 23, 2021. The copyright holder for this preprint (which was not certified by peer review) is the author/funder, who has granted medRxiv a license to display the preprint in perpetuity. It is made available under a CC-BY-NC 4.0 International license .

ALCP-O had a significant genetic correlation with 64 of the 99 preregistered phenotypes. We focus on the 35 traits related to substance use, personality, and other psychiatric outcomes (full results in Supplementary Table 2). Figure 2 depicts the difference in genetic correlations $\left(r_{g}\right)$ between ALCP-O (yellow) and ALCP-S (teal), with the asterisks indicating whether a $r_{g}$ estimate for ALCP-S remained significantly different from zero after correcting for multiple testing. Across all traits, genetic correlations from ALCP-O to ALCP-S shrank towards zero, indicating that much of the genetic variance captured in the univariate alcohol problems GWAS reflects genetic variance broadly shared with other externalizing outcomes. For substance use, ALCP-O was genetically correlated with all other forms of substance use $\left(r_{g}=-.22-.82\right)$. Once we remove the shared variance due to EXT, ALCP-S was only associated with drinks per week $\left(r_{g}=.69\right)$ and age of smoking initiation $\left(r_{g}=.14\right)$, which switched directions. As expected, ALCP-O was genetically correlated with most of the impulsivity and personality phenotypes $\left(r_{g}=-.48-.56\right)$. Only neuroticism $\left(r_{g}=.33\right)$, lack of perseverance $\left(r_{g}=.37\right)$, and positive urgency $\left(r_{g}=.32\right)$ were correlated with ALCP-S. Finally, ALCP-O was genetically correlated with most forms of psychopathology $\left(r_{g}=-31-.49\right)$. ALCP-S remained associated with most of these traits, notably bipolar disorder $\left(r_{g}=.18\right)$, major depressive disorder $\left(r_{g}=0.23\right)$, and schizophrenia $\left(r_{g}=0.16\right)$. Overall, a substantial portion of the observed genetic correlations between problematic alcohol use and other phenotypes is due to genetic variants that operate via a broad externalizing liability. 
medRxiv preprint doi: https://doi.org/10.1101/2021.07.20.21260861; this version posted July 23, 2021. The copyright holder for this preprint (which was not certified by peer review) is the author/funder, who has granted medRxiv a license to display the preprint in perpetuity.

It is made available under a CC-BY-NC 4.0 International license .

Table 1: ALCP-O Lead SNPs across ALCP-O, EXT, and ALCP-S GWASs

\begin{tabular}{lccc|cc|cc|cc}
\hline & & & & \multicolumn{2}{c|}{ ALCP-O } & \multicolumn{2}{c|}{ EXT } & \multicolumn{2}{c}{ ALCP-S } \\
\hline SNP & CHR & BP & Nearest Gene & Dir & $-\log 10(\mathrm{P})$ & Dir & $-\log 10(\mathrm{P})$ & Dir & $-\log 10(\mathrm{P})$ \\
\hline rs10511087 & 3 & 85439136 & CADM2 & $\mathbf{+}$ & $\mathbf{8 . 4 1}$ & $\mathbf{+}$ & $\mathbf{4 8 . 1 5}$ & + & 3.26 \\
rs6842066 & 4 & 39393801 & RNU6-887P & - & $\mathbf{9 . 4 9}$ & + & 0.94 & - & $\mathbf{1 0 . 0 8}$ \\
rs28712821 & 4 & 39413780 & KLB & - & $\mathbf{1 1 . 0 4}$ & + & 0.81 & - & $\mathbf{1 1 . 6 1}$ \\
rs1229984 & 4 & 100239319 & ADH1B & - & $\mathbf{4 6 . 1 9}$ & + & 1.66 & - & $\mathbf{4 8 . 2 7}$ \\
rs3811802 & 4 & 100244221 & ADH1B & - & $\mathbf{1 4 . 1 9}$ & + & 1.06 & - & $\mathbf{1 4 . 9 8}$ \\
rs3114045 & 4 & 100252560 & ADH1C & - & $\mathbf{7 . 8 8}$ & + & 0.67 & - & $\mathbf{8 . 3 0}$ \\
rs4699743 & 4 & 100282103 & ADH1C & $\mathbf{+}$ & $\mathbf{8 . 2 9}$ & - & 0.57 & + & $\mathbf{8 . 6 7}$ \\
rs111466094 & 4 & 100408974 & RP11-696N14.3 & + & $\mathbf{8 . 1 5}$ & - & 2.06 & + & $\mathbf{9 . 1 3}$ \\
rs13135092 & 4 & 103198082 & SLC39A8 & + & $\mathbf{1 4 . 5 1}$ & + & 1.72 & + & $\mathbf{1 3 . 2 3}$ \\
rs34333163 & 4 & 103283117 & SLC39A8 & + & $\mathbf{7 . 5 1}$ & + & 1.37 & + & 6.72 \\
rs35277073 & 11 & 113350620 & DRD2 & $\mathbf{+}$ & $\mathbf{7 . 4 9}$ & + & 2.47 & + & 6.40 \\
\hline In
\end{tabular}

Independent lead SNPS from ALCP-O GWAS pruned for an LD threshold of $r^{2}<.1$

Bolded $=$ genome wide significant $\left(p<5 \times 10^{-8}\right)$

Table 1 presents the lead SNPs from the ALCP-O GWAS across the three GWA studies. In the ALCP-O GWAS, we identified 542 genome-wide significant $\left(p<5 \times 10^{-8}\right)$ SNPs before pruning for LD. Of these 542 SNPs, 465 were genome-wide significant in EXT ( 86\%) and 60 were genome-wide significant in ALCP-S $(\sim 11 \%)$ with no overlap between these two sets. Table 1 includes the 11 independent (LD threshold of $r^{2}<.1$ ) lead SNPs for ALCP-O, and the comparison with the EXT and ALCP-S GWAS results. Of these, only the locus on chromosome 3 (rs10511087), in the CADM2 region, was significant in the EXT GWAS, and the large number of SNPs before pruning were likely the result of a long-range LD region near CADM2. The lead SNP from another locus, located on chromosome 11, was in LD with one of the top SNPs from the EXT GWAS on NCAM1 (rs9919558, $p<6.50 \times 10^{-59}$ ). Notably, none of the SNPs on chromosome 4 were significant (or in LD) in the EXT GWAS. Instead, 8 of the 9 lead SNPs on chromosome 4 were significant in the ALCP-S GWAS. The top SNPs are in ADH1B and $A D H 1 C$, which are involved in alcohol metabolism, as well as other genes previously associated with alcohol phenotypes including $K L B$.

Gene-based analyses in MAGMA found 13 genes were significantly associated with ALCP-O, while only 2 genes were significant for ALCP-S. Analysis of tissue expression in 
medRxiv preprint doi: https://doi.org/10.1101/2021.07.20.21260861; this version posted July 23, 2021. The copyright holder for this preprint

(which was not certified by peer review) is the author/funder, who has granted medRxiv a license to display the preprint in perpetuity.

It is made available under a CC-BY-NC 4.0 International license .

MAGMA and H-MGAMA did not allow for comparisons because of the limited power in the ALCP-S results. Finally, in S-PrediXcan, only ADH1C was significantly associated with

ALCP-S. While these results do not point to any new biological pathways of risk, the biological sources of genetic variance across these different pathways reaffirm that EXT is capturing a broader risk domain, while ALCP-S is largely recapitulating genes specific to the pharmacokinetics of alcohol (see Supplementary Tables 7-10 for full results). 
medRxiv preprint doi: https://doi.org/10.1101/2021.07.20.21260861; this version posted July 23, 2021. The copyright holder for this preprint (which was not certified by peer review) is the author/funder, who has granted medRxiv a license to display the preprint in perpetuity.

\section{Polygenic Scores and Substance Use Disorders}

A

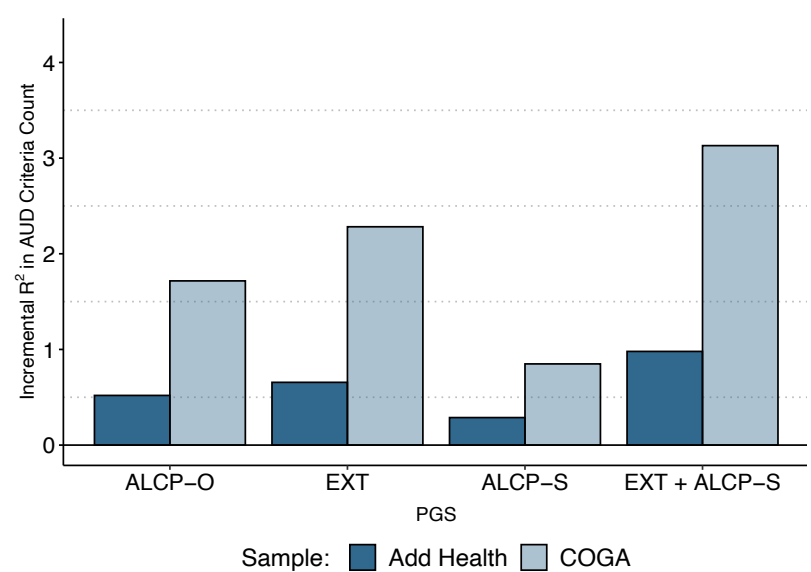

B

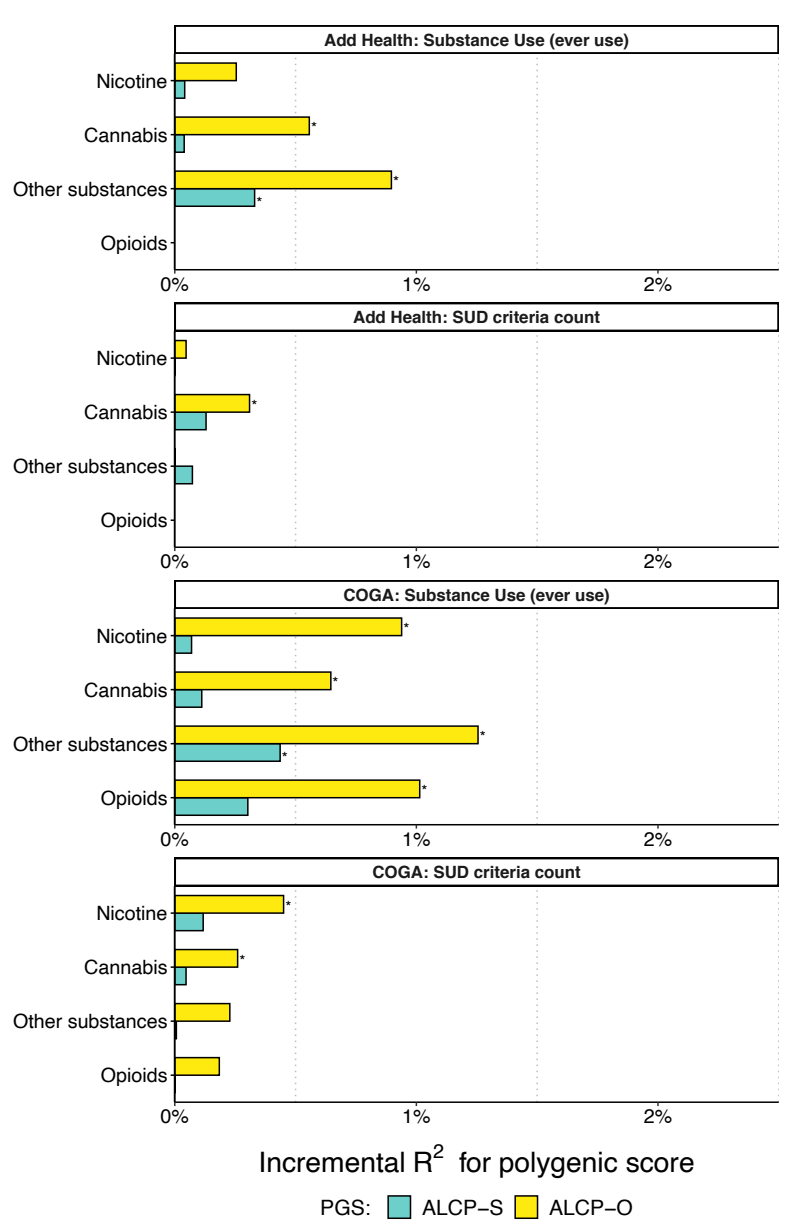

Figure 3: Polygenic Associations with Substance Use and Substance Use Disorders.

Bar charts illustrating the incremental proportion of variance (incremental $R 2$, or $\Delta R 2$ ) explained by the polygenic score in Add Health $(N=5,107)$ and COGA $(N=7,594)$. (A) Association between polygenic scores and lifetime AUD criterion counts. All polygenic scores were significantly associated with AUD criterion counts. (B) Association between polygenic scores and lifetime SUD criterion counts for cannabis, nicotine, other illicit substances, and opioids (COGA only). Asterisks $\left(^{*}\right)$ represent polygenic scores that are significant after correcting for an FDR of $5 \%$. 
medRxiv preprint doi: https://doi.org/10.1101/2021.07.20.21260861; this version posted July 23, 2021. The copyright holder for this preprint (which was not certified by peer review) is the author/funder, who has granted medRxiv a license to display the preprint in perpetuity. It is made available under a CC-BY-NC 4.0 International license.

Figure 3 illustrates associations between polygenic scores and various substance use phenotypes. Figure 3A presents the incremental $R^{2}\left(\Delta R^{2}\right)$ for criterion counts in AUD. Each PGS was significantly associated with AUD criteria after correcting for multiple testing (full results in Supplementary Table 3). The ALCP-O PGS explained $0.52 \%$ of the variance $\left(\triangle R_{A L C P-O}^{2}\right)$ in Add Health and $1.72 \%$ of the variance in COGA. When we compare the variance explained by ALCP-O to that from adding the externalizing and the alcohol specific PGS (EXT + ALCP-S) jointly to the baseline model, we see an improvement in predictive power in both Add Health $\left(\Delta R_{E X T+A L C P-S}^{2}=0.98 \%\right)$ and $\operatorname{COGA}\left(\Delta R_{E X T+A L C P-S}^{2}=3.13 \%\right)$.

Panel B includes other substances, in the forms of ever use and SUD criterion counts. The ALCP-O PGS is associated with cannabis use and other substance use in Add Health $\left(\mathrm{OR}_{A L C P-O}=1.15-1.20, \Delta R^{2}=0.56-0.90 \%\right)$ and all forms of use in COGA $\left(\mathrm{OR}_{A L C P-O}=1.20-1.27\right.$ $\left.\Delta R^{2}=0.65-1.26 \%\right)$. Additionally, the ALCP-O PGS is associated with cannabis use disorder criteria in both COGA and Add Health $\left(\beta_{A L C P-O}=0.11-0.16, \Delta R^{2}=0.26-0.31 \%\right)$, and nicotine dependence criteria in COGA $\left(\beta_{A L C P-O}=0.20, \Delta R^{2}=0.45 \%\right)$. However, the ALCP-S PGS was only associated with ever using illicit substances (other than cannabis) and the associations are attenuated compared to that of ALCP-O $\left(\mathrm{OR}_{A L C P-S}=1.12-1.15, \Delta R^{2}=0.33-0.44 \%\right)$. These results indicate that our multivariate analyses successfully identified variants more specifically associated with problematic alcohol use, similar to previous GWAS-by-subtraction designs ${ }^{23}$. 
medRxiv preprint doi: https://doi.org/10.1101/2021.07.20.21260861; this version posted July 23, 2021. The copyright holder for this preprint (which was not certified by peer review) is the author/funder, who has granted medRxiv a license to display the preprint in perpetuity. It is made available under a CC-BY-NC 4.0 International license .

\section{Polygenic Scores and Longitudinal Models of Alcohol Misuse}

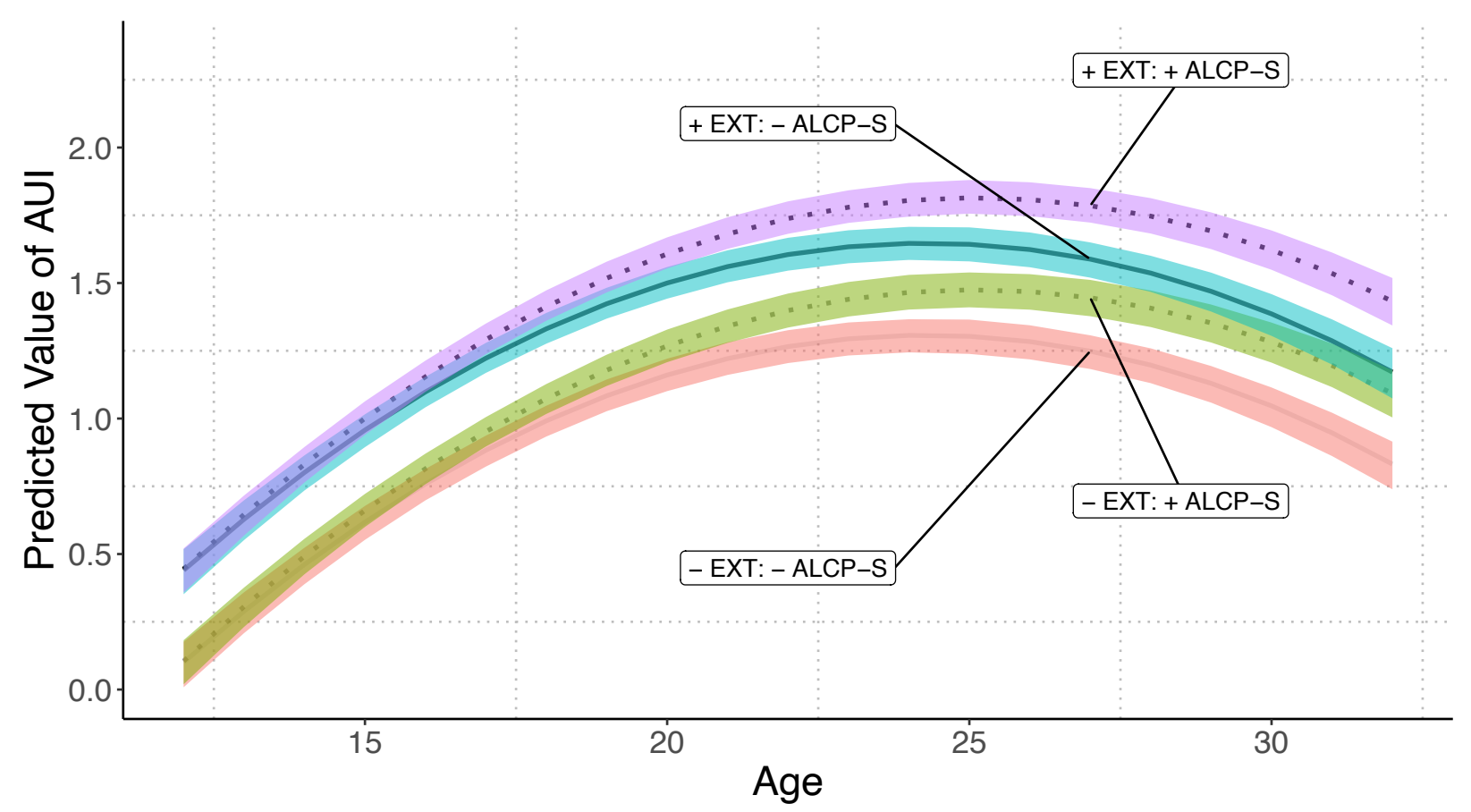

Figure 4: Longitudinal Models of Polygenic Associations with Alcohol Use and Misuse

Predicted values for alcohol use index (AUI) from ages 12 to 32 using linear mixed models in Add Health ( $N=5,107)$. Values for EXT and ALCP-S polygenic scores set to $\pm 1.5 \mathrm{SD}$. The shaded areas represent $95 \%$ confidence intervals. Confidence intervals estimated using percentile method bootstrapping over 1000 bootstrap samples. All other covariates set to mean values

Lastly, we fit a series of longitudinal growth models for a composite alcohol use index (AUI) in Add Health using linear mixed models (see Supplementary Note 4.5 for complete results). The best fitting model followed a quadratic change in AUI over time (with sex differences in slope), a significant association between EXT PGS and base levels of AUI $\left(\beta_{E X T}=\right.$ 0.12, $\mathrm{SE}_{E X T}=0.01, P_{E X T}=1.46 \times 10^{-18}$ ), and a significant association between ALCP-S PGS and change in the linear component of age for $\mathrm{AUI}\left(\beta_{A L C P-S^{*} A G E}=0.07, \mathrm{SE}_{A L C P-S^{*} A G E}=0.02, P_{A L C P-S^{*} A G E}\right.$ $=5.70 \times 10^{-5}$ ). We found no evidence of sex-specific effects of either PGS in stratified models.

Figure 4 provides a visual representation of the results from this best fitting longitudinal model across levels of each PGS ( $\pm 1.5 \mathrm{SD}$ ). Individuals higher on EXT PGS experience higher levels 
medRxiv preprint doi: https://doi.org/10.1101/2021.07.20.21260861; this version posted July 23, 2021. The copyright holder for this preprint (which was not certified by peer review) is the author/funder, who has granted medRxiv a license to display the preprint in perpetuity. It is made available under a CC-BY-NC 4.0 International license.

of AUI across time and sex, whereas those with higher levels of ALCP-S experience increased growth in AUI.

\section{Discussion}

Genetic influences on SUDs can operate via both shared genetic risk with other forms of externalizing as well as via substance specific pathways. Conventional analyses focused on a single phenotype, what we would term the "classical" GWAS approach, are unable to differentiate these pathways; newer multivariate approaches begin to make this possible. In the current analysis, we demonstrated the potential of disaggregating genetic variance in problematic alcohol use into risk shared with other externalizing behaviors/disorders, and risk that is specific to problematic alcohol use. We demonstrate that multivariate genomic analyses of correlated traits can increase the specificity for characterizing how genetic risk unfolds.

When we compared the results from the univariate ALCP-O GWAS to those from the multivariate model (EXT and ALCP-S), we found robust evidence of distinct pathways. We compared the genetic correlations for ALCP-O and ALCP-S across 99 preregistered phenotypes, focusing here on phenotypes related to personality, substance use, and psychopathology. ALCP-O was correlated with a broad range of personality phenotypes, especially those related to impulsivity. However, after removing the variance due to the shared risk for EXT, most of these associations were no longer significant. Similarly, ALCP-O was genetically correlated with multiple forms of other substance use phenotypes, while ALCP-S remained correlated only with alcohol consumption and age of smoking initiation, and this latter correlation switched direction. The change in direction likely reflects the fact that ALCP-S seems to be capture risk for problematic alcohol use once alcohol becomes available (early adulthood), forcing the correlation with age of smoking initiation to be positive. Lastly, ALCP-O was correlated with a variety of psychiatric phenotypes. Perhaps contrary to expectation, ALCP-S continued to yield small associations with many psychiatric traits, suggesting that ALCP-S still 
medRxiv preprint doi: https://doi.org/10.1101/2021.07.20.21260861; this version posted July 23, 2021. The copyright holder for this preprint (which was not certified by peer review) is the author/funder, who has granted medRxiv a license to display the preprint in perpetuity. It is made available under a CC-BY-NC 4.0 International license .

contains signal related to other disorders. Future expansions of the multivariate model to incorporate these other psychiatric conditions would presumably be able to further tease apart the residual genetic effects on problematic alcohol use.

At the SNP level, our approach was further able to separate alcohol-specific biology from a general risk towards externalizing, given that alcohol metabolizing genes (e.g., $A D H 1 B$ and ADH1C) were significant in the alcohol-specific results, but not EXT. We identified 11 lead SNPs after pruning for LD: one on chromosome 3, nine on chromosome 4, one on chromosome 11. In the ALCP-S GWAS, 8 of the 9 lead ALCP SNPs on chromosome 4 were genome-wide significant. These top SNPs were in alcohol metabolism genes ( $A D H 1 B$ and $A D H 1 C)$, and other genes previously associated with alcohol phenotypes including $K L B^{24,25}$. Additionally, SLC39A8 has been consistently identified as a risk variant for schizophrenia ${ }^{5,26}$. This association with SLC39A8 could indicate that the ALCP-S contains variance that is not unique to alcohol (e.g., risk for internalizing or psychotic disorders). Two of these ALCP-O SNPs were in strong LD $\left(r^{2} \sim\right.$ .98 ) with top SNPs from the EXT results. The SNP on chromosome 3 was in LD with two SNPs in the CADM2 region, while the SNP on chromosome 11 was in LD with a SNP on NCAM1. CADM2 has been implicated in previous GWAS of other substance use phenotypes ${ }^{27,28}$, risky behaviors $^{28-30}$, and impulsivity ${ }^{30}$. Overall, the SNP level results broadly point to two distinct pathways of risk: one related to risk taking/impulsivity, and one specific to the body's processing of alcohol, both of which are entwined in the univariate GWAS results for problematic alcohol use.

Finally, we evaluated polygenic scores in Add Health and COGA. Three notable findings emerge from the observed pattern of results. First, including PGS for both EXT and ALPC-S accounted for more variance in alcohol and other forms of substance use than the PGS for ALCP-O, underscoring the increase in power associated with incorporating information from genetically correlated traits ${ }^{10}$. Second, though the PGS from ALCP-O were associated with all forms of substance use, and SUD criteria, the PGS for ALCP-S were almost exclusively related 
medRxiv preprint doi: https://doi.org/10.1101/2021.07.20.21260861; this version posted July 23, 2021. The copyright holder for this preprint (which was not certified by peer review) is the author/funder, who has granted medRxiv a license to display the preprint in perpetuity. It is made available under a CC-BY-NC 4.0 International license.

to alcohol phenotypes, indicating that the model successfully differentiates shared and specific risk variants. Third, in longitudinal models, EXT was associated with higher mean-levels of AUI while ALCP-S was associated with increased growth in AUI. Notably, these results illustrate that externalizing genetic risk is associated with differences in AUl early in development. In contrast, during emerging adulthood, when alcohol use becomes legal and more readily accessible, there is further differentiation by alcohol-specific genetic risk. Therefore, alcohol-specific risk does not lead to alcohol problems without exposure to drinking, while broader externalizing risk captures propensity to drinking exposure across the life course. This longitudinal model reiterates the developmentally contextual nature of risk and recapitulates findings from prior studies using inferred measures of genetic risk from family-based designs ${ }^{31,32}$. Overall, the PGS results support the notion of a shared externalizing risk pathway and an alcohol-specific risk pathway.

Our analyses included several important limitations. First, they were limited to GWAS of European ancestries only. Unfortunately, Genomic SEM requires large sample sizes to obtain stable estimates of SNP-based heritability and genetic correlations. As larger sample sizes become available in more diverse ancestries, we will extend these models to those populations. Second, while we considered externalizing phenotypes, we did not include internalizing or psychotic disorders, which also show genetic overlap with $A U D^{33,34}$. Finally, our estimates of SNPs associated with ALCP-S were limited by the relatively small discovery sample size for ALCP-O (N 150K). Future iterations with more powerful GWAS of problematic alcohol ${ }^{3}$ use may reveal additional variants associated with ALCP-S.

GWAS of psychiatric disorders contain a mixture of different signals. Moving beyond univariate GWAS to multivariate designs offers the potential to tease apart these signals. We decomposed the genetic variation of problematic alcohol use into that which is shared with other externalizing phenotypes and that which is specific to problematic alcohol use. Comparison of results at multiple levels showed that variance specific to problematic alcohol use was related to alcohol phenotypes while that which was shared was more strongly related to other substance 
medRxiv preprint doi: https://doi.org/10.1101/2021.07.20.21260861; this version posted July 23, 2021. The copyright holder for this preprint (which was not certified by peer review) is the author/funder, who has granted medRxiv a license to display the preprint in perpetuity. It is made available under a CC-BY-NC 4.0 International license .

use and impulsivity. Differentiating these pathways of risk will become more important as genetic data becomes incorporated into clinical practice and we move towards an era of precision medicine.

\section{Acknowledgments}

The Externalizing Consortium: Principal Investigators: Danielle M. Dick, Philipp Koellinger, K. Paige Harden, Abraham A. Palmer. Lead Analysts: Richard Karlsson Linnér, Travis T.

Mallard, Peter B. Barr, Sandra Sanchez-Roige. Significant Contributors: Irwin D. Waldman. The Externalizing Consortium has been supported by the National Institute on Alcohol Abuse and Alcoholism (R01AA015416 - administrative supplement), and the National Institute on Drug Abuse (R01DA050721). Additional funding for investigator effort has been provided by K02AA018755, U10AA008401, P50AA022537, as well as a European Research Council Consolidator Grant (647648 EdGe to Koellinger). The content is solely the responsibility of the authors and does not necessarily represent the official views of the above funding bodies. The Externalizing Consortium would like to thank the following groups for making the research possible: Add Health, Vanderbilt University Medical Center's BioVU, Collaborative Study on the Genetics of Alcoholism (COGA), the Psychiatric Genomics Consortium's Substance Use Disorders working group, UK10K Consortium, UK Biobank, and Philadelphia Neurodevelopmental Cohort. We would also like to thank the research participants and employees of 23andMe, Inc. for making this work possible. The full set of externalizing GWAS summary statistics can be made available to qualified investigators who enter into an agreement with 23 andMe that protects participant confidentiality. Once the request has been approved by 23andMe, a representative of the Externalizing Consortium can share the full set of summary statistics. All code necessary to replicate this study is available upon request. 
medRxiv preprint doi: https://doi.org/10.1101/2021.07.20.21260861; this version posted July 23, 2021. The copyright holder for this preprint (which was not certified by peer review) is the author/funder, who has granted medRxiv a license to display the preprint in perpetuity. It is made available under a CC-BY-NC 4.0 International license .

\section{References}

1. Zhou H, Rentsch CT, Cheng Z, et al. Association of OPRM1 Functional Coding Variant With Opioid Use Disorder: A Genome-Wide Association Study. JAMA Psychiatry. Published online June 2020. doi:10.1001/jamapsychiatry.2020.1206

2. Johnson EC, Demontis D, Thorgeirsson TE, et al. A large-scale genome-wide association study meta-analysis of cannabis use disorder. The Lancet Psychiatry. Published online 2020. doi:10.1016/S2215-0366(20)30339-4

3. Zhou H, Sealock JM, Sanchez-Roige S, et al. Genome-wide meta-analysis of problematic alcohol use in 435,563 individuals yields insights into biology and relationships with other traits. Nat Neurosci. Published online 2020. doi:10.1038/s41593-020-0643-5

4. Levey DF, Stein MB, Wendt FR, et al. Bi-ancestral depression GWAS in the Million Veteran Program and meta-analysis in $>1.2$ million individuals highlight new therapeutic directions. Nat Neurosci. Published online May 27, 2021. doi:10.1038/s41593-021-00860-2 5. Ripke S, Neale BM, Corvin A, et al. Biological insights from 108 schizophreniaassociated genetic loci. Nature. 2014;511(7510):421-427. doi:10.1038/nature13595

6. Sanchez-Roige S, Palmer AA, Clarke TK. Recent Efforts to Dissect the Genetic Basis of Alcohol Use and Abuse. Biol Psychiatry. Published online 2020.

doi:10.1016/j.biopsych.2019.09.011

7. Kendler KS, Myers J. The boundaries of the internalizing and externalizing genetic spectra in men and women. Psychol Med. 2014;44(3):647-655.

doi:10.1017/S0033291713000585

8. Kendler KS, Prescott CA, Myers J, Neale MC. The structure of genetic and environmental risk factors for common psychiatric and substance use disorders in men and women. Arch Gen Psychiatry. 2003;60(9):929-937. doi:10.1001/archpsyc.60.9.929 
medRxiv preprint doi: https://doi.org/10.1101/2021.07.20.21260861; this version posted July 23, 2021. The copyright holder for this preprint (which was not certified by peer review) is the author/funder, who has granted medRxiv a license to display the preprint in perpetuity. It is made available under a CC-BY-NC 4.0 International license.

9. Krueger RF, Hicks BM, Patrick CJ, Carlson SR, lacono WGWG, McGue M. Etiological connections among substance dependence, antisocial behavior and personality: Modeling the externalizing spectrum. J Abnorm Psychol. 2002;111(3):411-424. doi:10.1037//0021$843 x .111 .3 .411$

10. Grotzinger ADD, Rhemtulla M, Vlaming R de de, et al. Genomic structural equation modelling provides insights into the multivariate genetic architecture of complex traits. Nat Hum Behav. Published online April 2019. doi:10.1038/s41562-019-0566-x

11. Grotzinger AD, Mallard TT, Akingbuwa WA, et al. Genetic Architecture of 11 Major Psychiatric Disorders at Biobehavioral, Functional Genomic, and Molecular Genetic Levels of Analysis. medRxiv. Published online January 1, 2020:2020.09.22.20196089.

doi:10.1101/2020.09.22.20196089

12. Karlsson Linner R, Mallard TT, Barr PB, et al. Multivariate genomic analysis of 1.5 million people identifies genes related to addiction, antisocial behavior, and health. Nat Neurosci. Published online January . $\mathrm{h}$

13. Benjamini Y, Hochberg Y. Controlling the False Discovery Rate: A Practical and Powerful Approach to Multiple Testing. J R Stat Soc Ser B. 1995;57(1):289-300. http://www.jstor.org/stable/2346101

14. Watanabe K, Taskesen E, van Bochoven A, Posthuma D. Functional mapping and annotation of genetic associations with FUMA. Nat Commun. 2017;8(1):1-11.

doi:10.1038/s41467-017-01261-5

15. de Leeuw CA, Mooij JM, Heskes T, Posthuma D. MAGMA: Generalized Gene-Set Analysis of GWAS Data. PLOS Comput Biol. 2015;11(4):e1004219.

doi:10.1371/journal.pcbi.1004219

16. Sey NYA, Hu B, Mah W, et al. A Computational Tool (H-MAGMA) for Improved Prediction of Brain-Disorder Risk Genes by Incorporating Brain Chromatin Interaction Profiles.; 2020. 
medRxiv preprint doi: https://doi.org/10.1101/2021.07.20.21260861; this version posted July 23, 2021. The copyright holder for this preprint (which was not certified by peer review) is the author/funder, who has granted medRxiv a license to display the preprint in perpetuity. It is made available under a CC-BY-NC 4.0 International license .

17. Barbeira A, Pividori M, Zheng J, Wheeler H, Nicolae D, Im HK. Integrating Predicted Transcriptome From Multiple Tissues Improves Association Detection. Integr Predict Transcr from Mult tissues Improv Assoc Detect. Published online 2018:292649. doi:10.1101/292649

18. Harris KM. The Add Health Study: Design and Accomplishments. Published online 2013. doi:https://doi.org/10.17615/C6TW87

19. Begleiter H, Reich T, Hesselbrock V, et al. The collaborative study on the genetics of alcoholism. Alcohol Health Res World. 1995;19(3):228.

20. Edenberg HJ, Alcohol Res $\mathrm{H}$. The collaborative study on the genetics of alcoholism: an update. Alcohol Res Heal. 2002;26(3):214-218.

21. Ge T, Chen C-Y, Ni Y, Feng Y-CA, Smoller JW. Polygenic prediction via Bayesian regression and continuous shrinkage priors. Nat Commun. 2019;10(1):1776.

doi:10.1038/s41467-019-09718-5

22. Vachon DD, Krueger RF, Irons DE, lacono WG, McGue M. Are Alcohol Trajectories a Useful Way of Identifying At-Risk Youth? A Multiwave Longitudinal-Epidemiologic Study. J Am Acad Child Adolesc Psychiatry. 2017;56(6):498-505. doi:10.1016/j.jaac.2017.03.016

23. Belsky DW, Paige Harden K, Nivard MG, et al. Investigating the genetic architecture of noncognitive skills using GWAS-by-subtraction. doi:10.1038/s41588-020-00754-2

24. Liu M, Jiang $\mathrm{Y}$, Wedow $\mathrm{R}$, et al. Association studies of up to 1.2 million individuals yield new insights into the genetic etiology of tobacco and alcohol use. Nat Genet. 2019;51(2):237244. doi:10.1038/s41588-018-0307-5

25. Clarke TK, Adams MJ, Davies G, et al. Genome-wide association study of alcohol consumption and genetic overlap with other health-related traits in UK Biobank ( $N=112117)$. Mol Psychiatry. 2017;22:1376.

doi:10.1038/mp.2017.153https://www.nature.com/articles/mp2017153\#supplementaryinformation 
medRxiv preprint doi: https://doi.org/10.1101/2021.07.20.21260861; this version posted July 23, 2021. The copyright holder for this preprint (which was not certified by peer review) is the author/funder, who has granted medRxiv a license to display the preprint in perpetuity. It is made available under a CC-BY-NC 4.0 International license .

26. Mealer RG, Jenkins BG, Chen CY, et al. The schizophrenia risk locus in SLC39A8 alters brain metal transport and plasma glycosylation. Sci Rep. 2020;10(1). doi:10.1038/s41598-02070108-9

27. Pasman JA, Verweij KJH, Gerring Z, et al. GWAS of lifetime cannabis use reveals new risk loci, genetic overlap with psychiatric traits, and a causal influence of schizophrenia. Nat Neurosci. 2018;21(9):1161-1170. doi:10.1038/s41593-018-0206-1

28. Arends RM, Pasman JA, Verweij KJH, et al. Associations between the CADM2 gene, substance use, risky sexual behavior, and self-control: A phenome-wide association study. Addict Biol. 2021;n/a(n/a):e13015. doi:https://doi.org/10.1111/adb.13015

29. Karlsson Linnér R, Biroli P, Kong E, et al. Genome-wide association analyses of risk tolerance and risky behaviors in over 1 million individuals identify hundreds of loci and shared genetic influences. Nat Genet. 2019;51(2):245-257. doi:10.1038/s41588-018-0309-3

30. Sanchez-Roige S, Fontanillas P, Elson SL, et al. Genome-Wide Association Studies of Impulsive Personality Traits (BIS-11 and UPPS-P) and Drug Experimentation in up to 22,861 Adult Research Participants Identify Loci in the CACNA1I and CADM2 genes. J Neurosci. 2019;39(13):2562. doi:10.1523/JNEUROSCI.2662-18.2019

31. Meyers JL, Salvatore JE, Vuoksimaa E, et al. Genetic Influences on Alcohol Use Behaviors Have Diverging Developmental Trajectories : A Prospective Study Among Male and Female Twins. Alcohol Clin Exp Res. 2014;38(11):2869-2877. doi:10.1111/acer.12560

32. Kendler KS, Gardner C, Dick DM. Predicting alcohol consumption in adolescence from alcohol- specific and general externalizing genetic risk factors, key environmental exposures and their interaction. Psychol Med. 2011;41(7):1507-1516.

doi:10.1017/S003329171000190X.Predicting

33. Howard DM, Adams MJ, Clarke T-KK, et al. Genome-wide meta-analysis of depression identifies 102 independent variants and highlights the importance of the prefrontal brain regions. Nat Neurosci. 2019;22(3):343. doi:10.1038/s41593-018-0326-7 
medRxiv preprint doi: https://doi.org/10.1101/2021.07.20.21260861; this version posted July 23, 2021. The copyright holder for this preprint (which was not certified by peer review) is the author/funder, who has granted medRxiv a license to display the preprint in perpetuity.

It is made available under a CC-BY-NC 4.0 International license .

34. Walters RK, Polimanti R, Johnson EOECEO, et al. Trans-ancestral GWAS of alcohol dependence reveals common genetic underpinnings with psychiatric disorders. Nat Neurosci.

2018;21(12):1656-1669. doi:10.1038/s41593-018-0275-1 